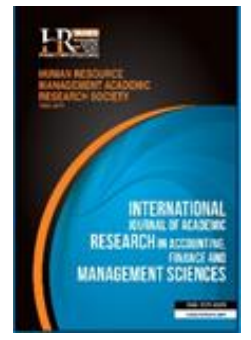

International Journal of Academic Research in Accounting, Finance and Management Sciences

Vol. 9, No.4, October 2019, pp. 98-117

E-ISSN: 2225-8329, P-ISSN: 2308-0337

(C) 2019 HRMARS

www.hrmars.com

To cite this article: Kapaya, S. M. (2019). Financial System and Economic Development in Africa: A Review and Policy

Recommendations, International Journal of Academic Research in Accounting, Finance and Management Sciences

$9(4): 98-117$

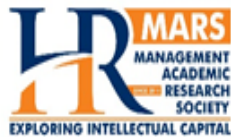

http://dx.doi.org/10.6007/IJARAFMS/v9-i4/6726 (DOI: 10.6007/IJARAFMS/v9-i4/6726)

\title{
Financial System and Economic Development in Africa: A Review and Policy Recommendations
}

\author{
Saganga M. Kapaya \\ Department of Accounting and Finance, Faculty of Business Management, The Open University of Tanzania, P.O. Box \\ 23409, Dar es Salaam, Tanzania, E-mails: saganga.kapaya@out.ac.tz, kapaya.saganga@gmail.com
}

\begin{abstract}
This paper gears towards expounding the role, capacity, suitability, challenges and solutions for African financial systems in enhancing economic growth. This article employs a quasi-meta-analysis method of literature where an online search of materials related to the field of financial system and economic development were visited. Several journal publishers were included in finding the materials for this review. Search words and synonyms were used in the search processes, the reviewed papers were used in discussing the related issues in the topic. It shows that, both theoretically and empirically, a financial system in an economy facilitates the following roles: first, it enables transfer of resources through time, across borders and among economic entities. Second, it facilitates mobilization and pooling of savings. Third, it facilitates the allocation of capital competitively. The reviewed evidences show that, Africa's financial systems have this functionality potential if there will be among others; liberalization of economies, strengthening of legal framework and expansion of tax and investor bases. The African situation needs to seek innovative financial products such as Islamic bonds, sovereign bonds and diaspora bonds. Empower local/municipal governments' role in raising finance through municipal bonds. Discharge differential financial policies to suit characteristics of the African populations. Implement agenda on ICT, information sharing, and sensitization on savings and promote financial inclusion at all levels of financial intermediation. This article attempts to deduce from empirical evidences specific implications and link them to both policy and practical realities for the linkage between financial development and economic development in the African experiences. No prior article has attempted to look at this issue in this light within the African context.
\end{abstract}

Key words Financial System, African Economies, Economic Development

Received: 06 Dec 2019 (C) The Authors 2019

Revised: 19 Dec 2019 Published by Human Resource Management Academic Research Society (www.hrmars.com)

Accepted: 25 Dec 2019 This article is published under the Creative Commons Attribution (CC BY 4.0) license. Anyone may reproduce, distribute, translate and create derivative works of this article (for both commercial and non-commercial purposes), subject to full attribution to the original publication and authors. The full terms of this license may be seen at: http://creativecommons.org/licences/by/4.0/legalcode

\section{Introduction}

The desire for unity and integration is growing from all corners in Africa. More and more individuals at different levels of policy-making, academics, politics and governance are pushing for this end. Africa realizes that it has an abundance of resources but weak structure to facilitate its exploitation, and even if exploited; how best to mobilize, pool, allocate, transfer, ensure and price its' vast resources to its' economic advantages. Other continents, such as Asia and South America have been able to accomplish this through their financial systems. These processes have not yet received the deserved attention in Africa. The bulk sizes of resources in Africa need much bigger, efficient and effective financial system infrastructures. The much-needed bigger projects that need bigger financing require much bigger market structures. While the African financial systems are numerous and disjointed the palpable solution to such a quandary is 
financial systems integration at different levels, policy redressing, fine-tuning of the legal framework and addressing market inadequacies as hereafter discussed.

The aim of this review is to identify strength, weaknesses in financial development and recommend best policy and practices measure in African economies by deriving knowledge from successful economies and related frontier financial system policies and practices from African experiences.

This article employs a quasi-meta-analysis method of literature where an online search of materials related to the field of financial system and economic development were visited. Several journal publishers were included in finding the materials for this review. They included emeraldinsight.com, jsor.com, scinceconnect.com, sciencedirect.com, elsevier.com and tandfonline.com. several key words and synonyms were used in searching for these materials, they included but not limited to "financial system", "financial development", "financing", "financial markets", "bond markets", "banking system", "equity/capital markets", "resource mobilization", "resource allocation", "financial deepening", "financial inclusion", "financial deepening/inclusion", "financial information sharing" and "economic growth/development", among other search words and synonyms. An attempt was made to synthesize the current understanding on the link between financial development and economic development and point out some dedicated recommendations for policy and practice in the African context.

\section{Mobilizing local, regional resources and reforms}

The Sustainable Development Goal (SDG) and the global development agenda for 2015 and 2030 require large resource mobilization (Ahmed et al., 2015). There is a great awakening among policy makers and researchers alike in developing countries as to the importance of resources mobilization at local levels. The Conference on Financing held in Addis Ababa Ethiopia, on July 2015 puts to action Agenda 2063, which envisions the structural transformation for Africa within 50 years. Particularly, one of the successful outcomes of the agenda is strengthening of domestic resources mobilization (DRM) and control of illegal flow of capital out of the continent. The measures aim to build Africa driven by its own people and resources (Nnadozie et al., 2017). There is a notable growing international interest in strengthening DRM. Africa however has paid little attention to what it needs to succeed in DRM, efficient allocation and utilization of the mobilized resources.

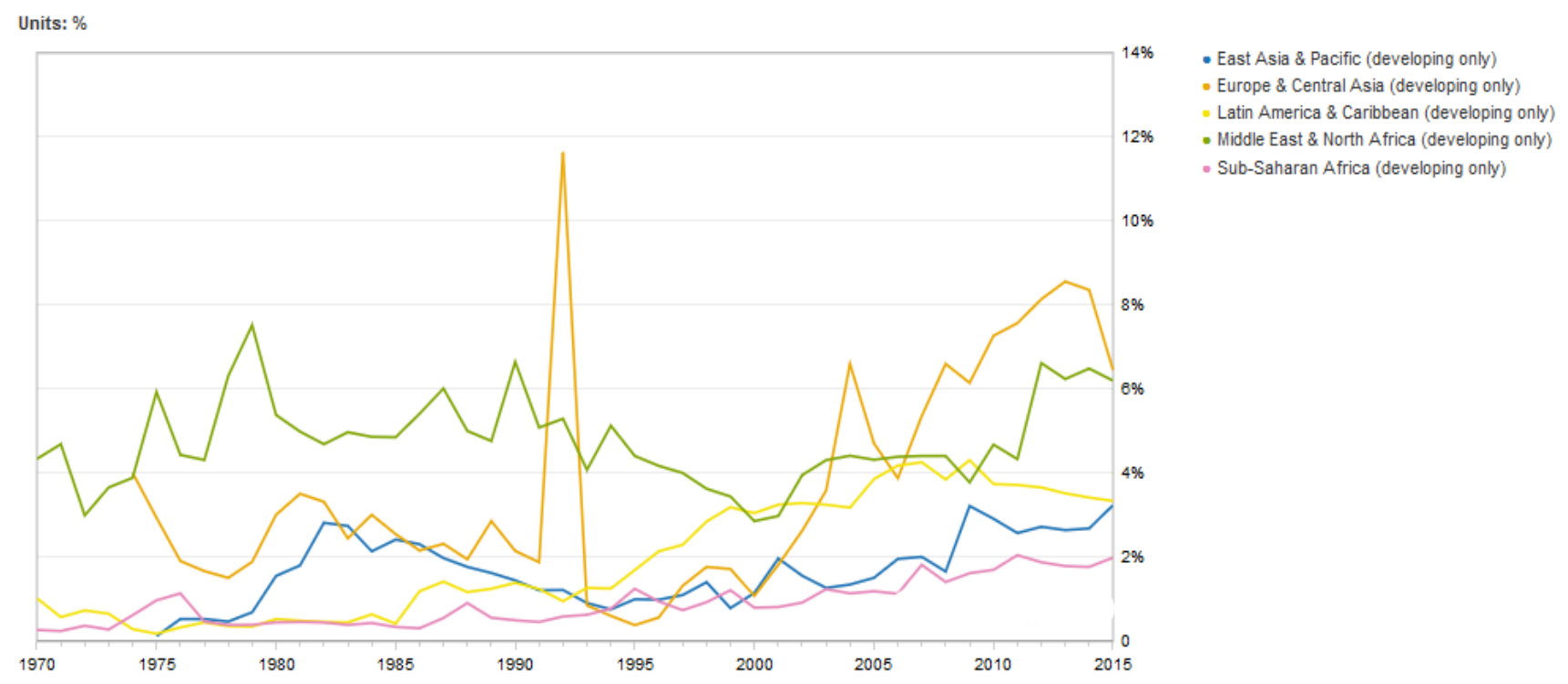

Figure 1. Comparable regions remittances inflows to GDP (\%) (I.e. Workers' remittances and compensation of employees comprise current transfers by migrant workers and wages and salaries earned by nonresident workers)

Source: World Bank (citing, International Financial Statistics (IFS), International Monetary Fund (IMF)) (July, 2018)

The evidences indicate that financing ambitious projects in a country depends on marshaling local country level indigenous capacities (World Bank, 2013). Mobilizing local resources is one arm to the matter; 
the other arm needs to address policies and economic measures that address mobilization of international resources. These represent themselves as remittances, foreign direct investments (FDIs), foreign loans, Islamic finance (bonds), sovereign bonds, diaspora bonds, grants and control over illicit capital flows among others. For instance, remittances flow to Sub-Saharan Africa (SSA) is very low with only $2 \%$ of GDP high in 2015 (Figure 1) while comparable regions have up to 6\% of GDP in the same period. For instance, the mobilization of international private debt securities in SSA has been cyclical and slowly growing (Figure 10). More can be done to take advantage of these financial resource sources.

High DRM successes help reduce dependency levels on foreign economies. Many of low-income African economies have high official development assistance (ODA) as part of external resources. Development of a financial system depends on high levels of domestic savings. There are well-noted evidences indicating conceivable relationship between savings, investments and economic growth (Nnadozie et al., 2017). Unlike domestic resources, foreign resources sometimes wear gloves and miss the mark at the same time. For instance, FDIs address specific private investments in host countries, remittances mostly go directly to immediate consumptions by the recipients and foreign aids normally gears towards strategic goals of donors. Domestic resources (e.g. through savings, taxations, loans etc.) are more reliable and they have the capacity to create social accountability and responsibility. They create domestic ownership of the development process (UNCTAD, 2013).

Gross domestic saving (GDS) rates (Figure 1) for SSA are declining over years since 1981 to 2017 as compared to other comparable developing country-regions such as East Asia \& Pacific (excluding high income) (EAP), Europe \& Central Asia (excluding high income) (ECA), Latin America \& Caribbean (excluding high income) (LAC), Middle East \& North Africa (MEA), Middle East \& North Africa (excluding high income) (MNA). For instance, in 2017 the GDS rates comparable regions are $43.6 \%$ in EAP, $32.9 \%$ in MEA, $26.9 \%$ in ECA, $24.8 \%$ in MNA and 18.9 in LAC. That of SSA is $18.9 \%$ in 2017 , which has declined from $38.6 \%$ in 1981 over time (Figure 2).

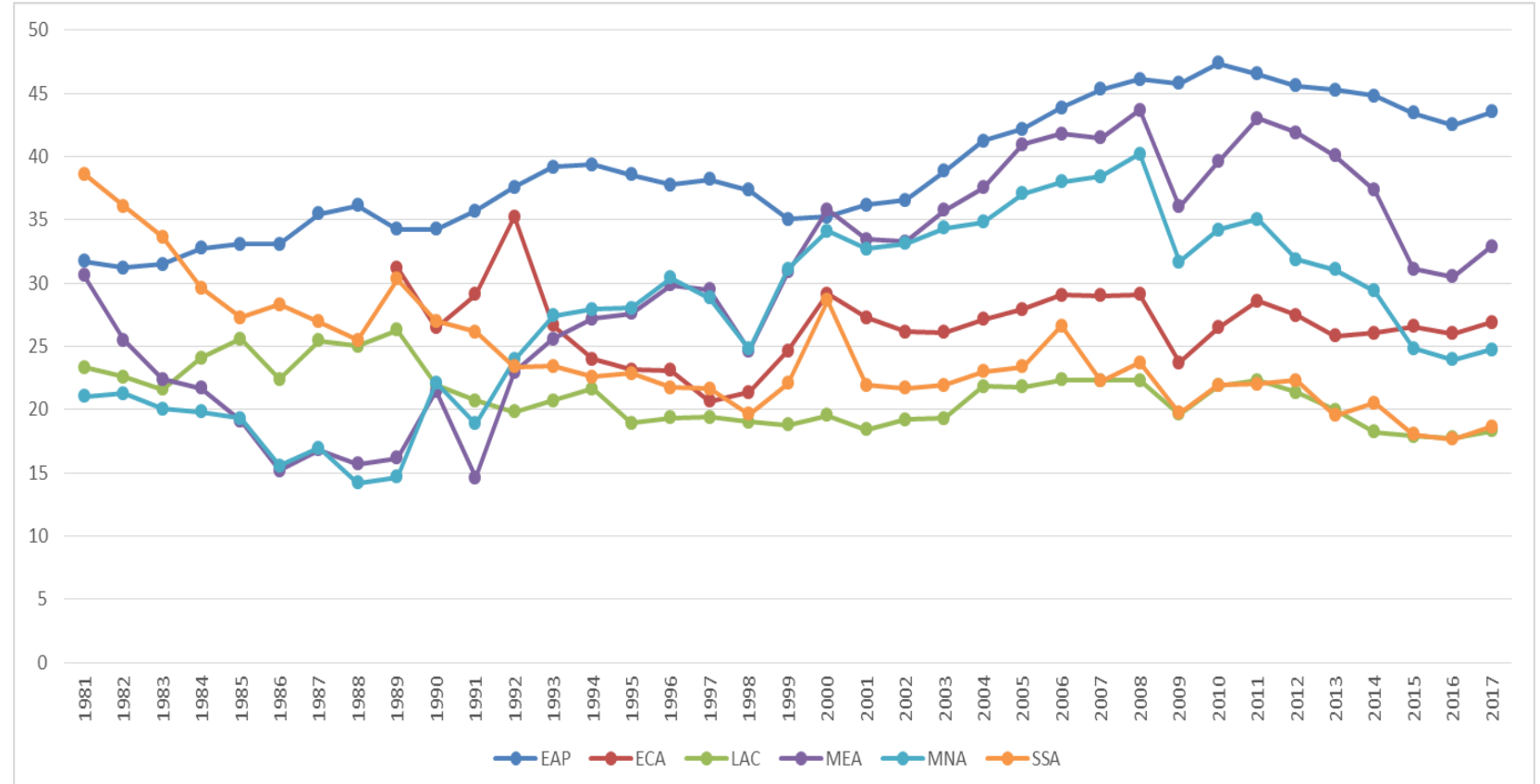

EAP: East Asia \& Pacific (excluding high income), ECA: Europe \& Central Asia (excluding high income), LAC: Latin America \& Caribbean (excluding high income) MEA: Middle East \& North Africa, MNA: Middle East \& North Africa (excluding high income), SSA: Sub-Saharan Africa

Figure 2. Gross domestic savings (\% of GDP) for selected comparable regions, 1981-2017

Source: World Bank national accounts data (World Bank, 2019)

Efforts may aim at resuscitating the declining GDS rates and capture the local resources potentials. On another level of DRM, high taxes despite disfavor from the external world have recently gained some impetus as a source of government finance from local sources. Most tax rates in SSA have tax to GDP rates that are above other comparable low-income regions (Figure 3). 


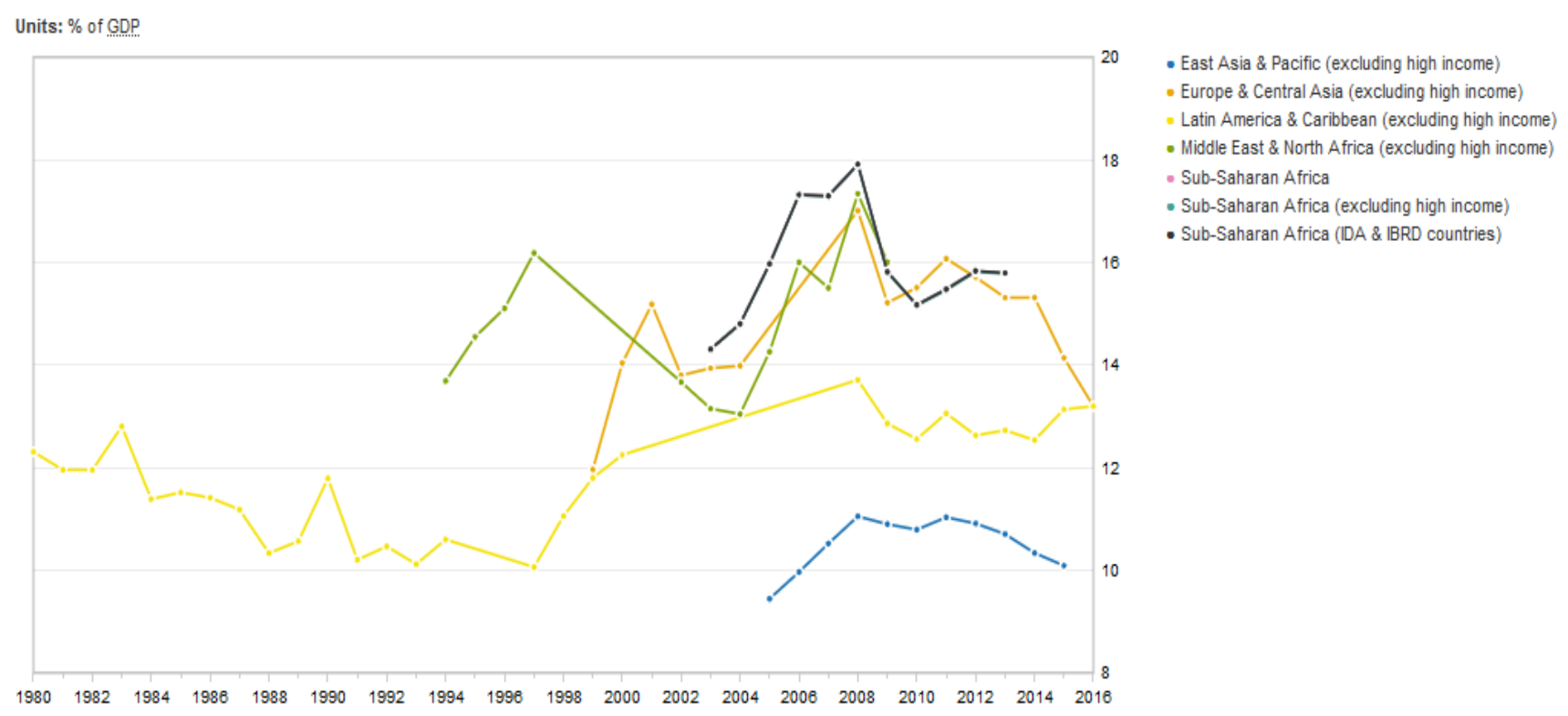

Figure 3. Comparable regions tax revenue to GDP (\%).

Source: World Bank (citing, International Financial Statistics (IFS), International Monetary Fund (IMF)) (July, 2018)

NOTE: Tax revenue refers to compulsory transfers to the central government for public purposes. Certain compulsory transfers such as fines, penalties, and most social security contributions are excluded. Refunds and corrections of erroneously collected tax revenue are treated as negative revenue.

NOTE: The International Development Association (IDA) is an international financial institution which offers concessional loans and grants to the world's poorest developing countries. The IDA is a member of the World Bank Group and is headquartered in Washington, D.C., United States.

NOTE: The International Bank for Reconstruction and Development (IBRD) is an international financial institution that offers loans to middle-income developing countries. The IBRD is the first of five member institutions that compose the World Bank Group, and is headquartered in Washington, D.C., United States

That means compared to other sources of public finance SSA is heavily relying on taxation to finance its development agendas. SSA may be making reasonable effort in the area of DRM but it is not up to financial demand quests. Some notable challenges in DRM hinge on heavy reliance on taxation that deters investments, weak financial infrastructure and governance frameworks (Nnadozie et al., 2017).

Nnadozie et al. (2017) assessing DRM capacities in African countries, deduce that majority of countries need to scale up on DRM in almost all areas. Particularly, they note a need for reforms in areas of taxation by increasing the tax base, promoting and attracting savings, and efficiently allocate them to essential areas for development. Challenges that need addressing relate to scaling up financial inclusion levels, improving legal and regulatory frameworks, technical and financial capacities. Knowledge sharing, training, sensitization programs at all levels and private-public partnerships. These in turn could be scaled up to regional and continental levels.

Bhushan (2013) explicates the significance of DRM through government revenue and domestic savings given the need to sustain strong economies. Africa is destined to outpace most of the economies in the world as evidenced by recent macroeconomic stability and growth in GDPs. It is true that increasing internal resources capacity enhances nation's policies ownership and more accountability on the part of citizens and governments. Economic success legends in South East Asia, China and India are enshrined in effective and high DRM level mobilization over time. There are more untapped potentials for DRM in Africa. Evidences underscore the fact that state resource mobilization (taxes, government revenues and private funds) are crucial for state building. There are numerous bottlenecks, which need rectifying. First, taxes bases are low, they need to be expanded; for example, the Tanzania Revenue Authority (TRA) has significantly increased the nation's tax base over the past three years. The use of computer-aided technologies in collection of taxes and fines has been able to reach most people. The tax payment procedural reforms have increased willingness and convenience in paying taxes. More sectors of the economy such as land registry, building taxes, small businesses taxes and reforms in the mining sectors 
taxes and government royalties and contracts are right moves that are ongoing. Second, private resources mobilization is vital. Private savings depend on income levels. The low incomes levels in SSA call for efforts that need to adjust the situation. Some nations, such as Tanzania have embarked on vigorous efforts to promote industrial growth and infrastructure development. The need to promote processing industries for value addition is politicized and implemented. All these require ample funding. Thirdly, majority of the population have no access to the financial sector. The agrarian population is notably excluded from the formal financial system. Although it is resource rich (in terms of land, crops and livestock, the agrarian sector often lacks commercial dispositions and is unmarried to the formal financial sector.

From the demand side of resource mobilization equitation the following are noted; in SSA, the level of capital market development is low (Figure 2). In some countries there are not long-term financing. Stock markets are weak, tantalized by insider trading and few listings. Corporate bonds are few and in some countries are non-existent (Bhushan, 2013). Secondary markets on government instruments and interbank lending are very nascent. The rates of capital markets capitalization are very low compared to other regions in the world (Figure 4, Figure 5). Development banks, community banks and cooperative banks are whimpering to death with majority closing or running into bankruptcy. All this led to precautionary saving behaviors and most held in non-financial forms such as real estates, livestock and commodities. While these challenges are overwhelming, the desire, need and necessity of enhancing DRM should stand at the foreface of the development agenda in SSA to ensure availability of resources to finance development. Tax reforms, legal reforms, and financial reforms are essential in order to achieve more outcomes. Some suggested reforms advanced by for instance Bhushan (2013) include, computerization and simplification of the taxation system, this particularly has reaped good collections in Tanzania. Promoting private DRM, enhancing financial sector information flow, increasing competition in the banking sector and decided efforts to develop capital markets.
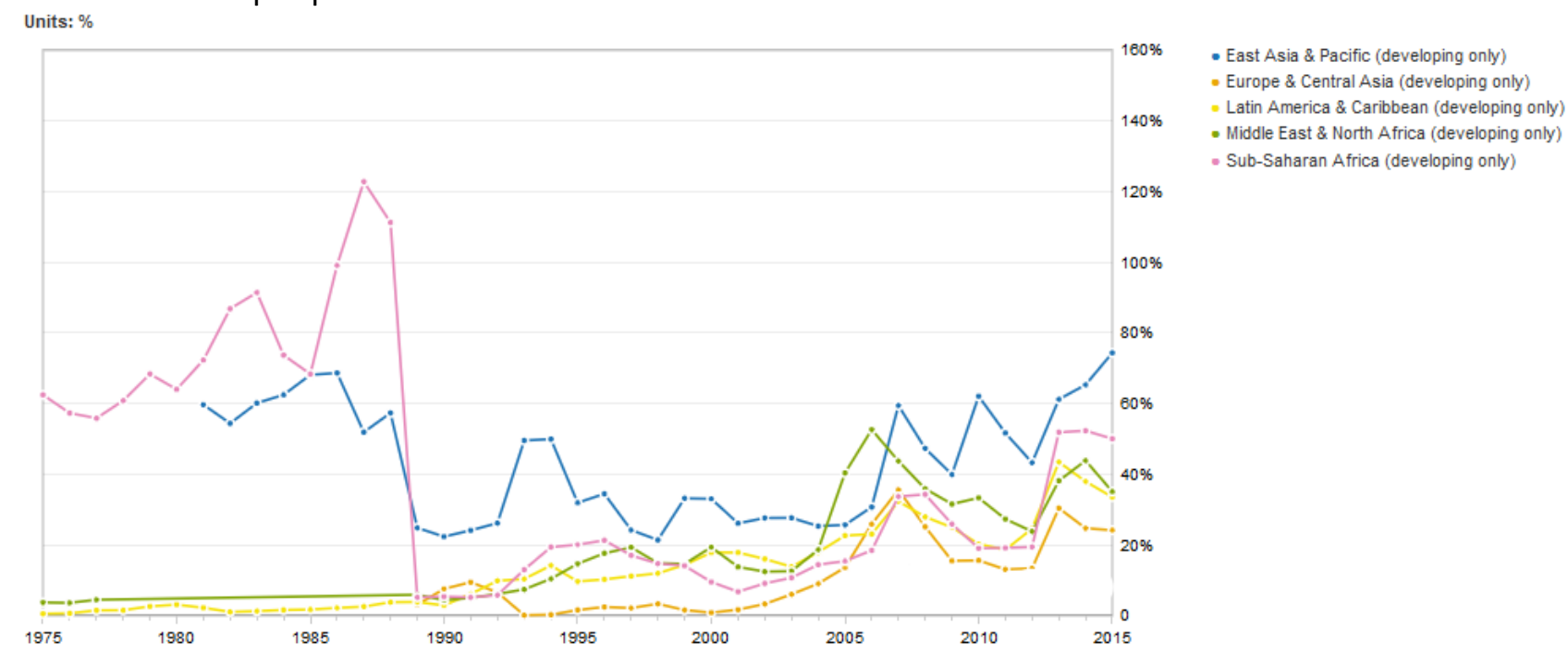

Figure 4. Comparable regions stock market capitalization to GDP (\%). (I.e. Value of listed shares to GDP)

Source: World Bank (citing, International Financial Statistics (IFS), International Monetary Fund (IMF)) (2018)

From the supply side of the resource mobilization equation the following are noted; comparatively, Beckmann (2019) reports in Europe and Central Asia only 38\% of adults save and only $8 \%$ of them save through formal channels. Karlan et al. (2014) associate savings with transaction costs, lack of trust, regulatory barriers, and information and knowledge gaps, social constrains and moral biases. Basing her study in Central European and Western Balkan states, she indicates that in these low-income countries, rates of savings are low and more frequently informal. Formal savings are predominantly in banks. There is as well lower capital market savings for such poor countries. Income has marginal effects on access to formal servings. Distance from formal financial institutions does not explain savings. Internet access influence savings. Less trust on banks influences formal savings negatively. It leads to informal savings 
options for the portion of population that want to save if they trust the informal options. These findings are well applicable in African counties since the situations are comparable.
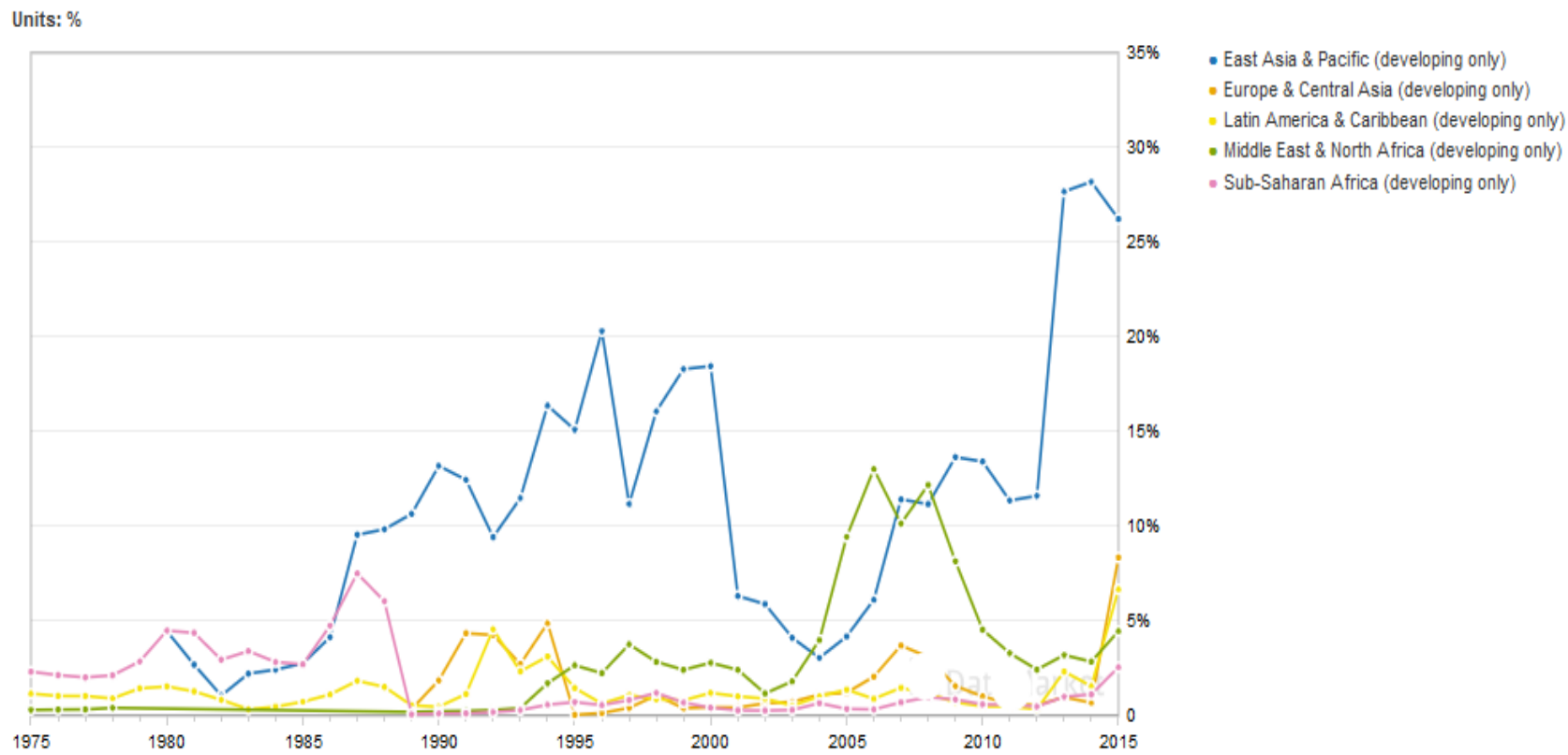

Figure 5. Comparable regions stock markets total value traded to GDP (\%). (I.e.Total value of all traded shares in a stock market exchange as a percentage of GDP)

Source: World Bank (citing, International Financial Statistics (IFS), International Monetary Fund (IMF)) (2018)

Poor families can and do save. Informal and bank savings are the most prominent type of savings in these families. Savings behaviors seem to be heterogeneous among individual and countries. Several factors constrain their saving baskets. Transaction costs associated with dealing with a bank, distance to banks, mistrust with banks, customer-relations concerns, (Beckmann, 2019), the level of financial inclusion basing on supply side factors such as banks density/concentration and low saving interest rates (Beckmann et al., 2019). The role of internet access increase stock markets participation and lowers the costs of transactions and information. Improving policies on internet, transaction costs, inclusion and promoting financial literacy may influence savings positively in SSA. Beckmann (2019) highlights the significance of memories of past bank crushes as having an impact on bank trusts. Policy has to address safeguards for bank customers' savings in time of bankruptcy. By representing savings into disaggregate variables (formal savings, cash savings, bank savings, contractual savings, capital market savings and one formal savings) and regressing against each for a set of household characteristics, she finds the following. Medium Education, Higher education, whether employed, whether retired, age, married, one-person household, financial loss during transition and having a loan, do positively, significantly and consistently affect the types of savings. Basing on the World Bank's goal of 'shared prosperity', which aspires to foster income growth among the bottom $40 \%$, a further analysis indicates that the bottom $40 \%$ saving behavior differ significantly from that of the top $60 \%$. The bottom $40 \%$ is disinclined to saving. The regression results indicate that, being a bottom $40 \%$ significantly and negatively affect each type of savings previously listed. This learning, if can be replicated, marks a call for divergent policies basing on disambiguation between the low-income groups and the high-income groups in SSA households. Policies also need to consider a classification of population based on characteristics that need to dictate policies on population groups for savings mobilization. For instance, agrarian population and small and medium enterprises should have different policies.

\section{State of financial systems, economic development and reforms}

Finance and economic theorists have both envisaged a positive link between financial development and economic development (Chauvet and Jacolin, 2017). Surprisingly, they have witnessed both negative and positive links between the two types of development. Economic theory hypothesizes a positive link 
between them. There are two main views, the first one contends that increase in demand for financial services results from economic development, the second view contends for a proactive effect of financial development on economic development. Thus, the levels of quality and quantities in financial services partly explain differences in economic developments in countries (Deltuvaite and Sinevičienè, 2014). This chapter mainly bases on this later proposition. African countries could realize more economic development if they will be able to give priorities to fine-tuning and reforming of its financial systems to its context and environment.

Studies indicate contradictory results on this issue, for instance some mutual causality, reverse causality and direct causality have been evidenced between financial development and economic development. Moreover, unlike in less developed economies, in some instances financial development have influenced economic development when an economy is already developed. As expected in European economies, Deltuvaitè and Sinevičienè (2014) find that financial development influences economic development. Conversely, in developing economies, where findings indicate a negative relationship between financial development and economic development, moderation effects of for instance information and communication technologies (ICT) penetration, review of legal frameworks, banking size and market concentration, reforms in capital markets, economic and financial restructuring and liberalization should be able to explain more on the anomalies (Fung, 2009; Bumann et al., 2013; Mitchener and Wheelock, 2013; Sassi and Goaied, 2013). One particular area of reform is liberalization of the financial system. Bumann et al., (2013) evidence a positive effect of financial liberalization on economic growth. Some policy measure could include removal of restrictions on capital in and out flow in forms of foreign direct investments (FDI). Uplifting of restrictions on equity capital movements in forms of international investments. Removal of banking sector legal restrictions coming in forms of credit controls, entry barriers, interest rate controls and restrictions on financial international transactions, and fostering privatization of governmental financial institutions. The following sub-sections discuss the various components and aspects of financial systems, roles on economic development and needed reforms.

\subsection{Capital markets depths and reforms}

Capital markets mainly comprise of stock markets and bond markets. They are an important source of long-term finance for both governments and corporations. Capital markets are essentially large by capitalization and number of listed firms in developed economies than in developing economies. Private bond markets are less frequent in developing economies. To develop these markets, introducing innovative instruments like mini-bonds and loan securitization should be in the agenda. The promotion of institutional investors seems to be attractive since their investments easily match with long-term finance horizons. Institutional investors come in various forms; they may include insurance companies, mutual funds and pension funds. Participation of institutional investors in developing countries is still low. The role of the government in long-term finance is within the range of market failure and economic and institutional weakness. Within this range, government policies and measures play crucial roles (Peria and Schmukler, 2017). For instance, promoting information flow mechanism, enriching the legal framework and enforcement by increasing judiciary independence, expanding the institutional frameworks through use of mutual funds, expanding collateral frameworks, and attracting both local and foreign investors. For instance, Peria and Schmukler (2017) show evidence that attracting foreign investors might extend debt maturities in developing economies which in turn add to financial stability.

\subsection{African bond markets and reforms}

Oji (2015) indicates that bond markets in Africa are shallow almost non-existent in most African countries. The dominant form of bonds is governmental ones (Figure 6).

Tyson (2015) indicates that Sub-Sahara Africa (SSA) complacence may force it to repeat the mistakes that occurred in Asia and Latin America in the early 1990s due to disruptions in the financial system that led to financial crises that drove many for a decade in poverty. There are prospects however for development of bond markets in Africa. There are strong evidence of issuances in 2013 and 2014 (Figure 6, Figure 7 and Figure 8). 


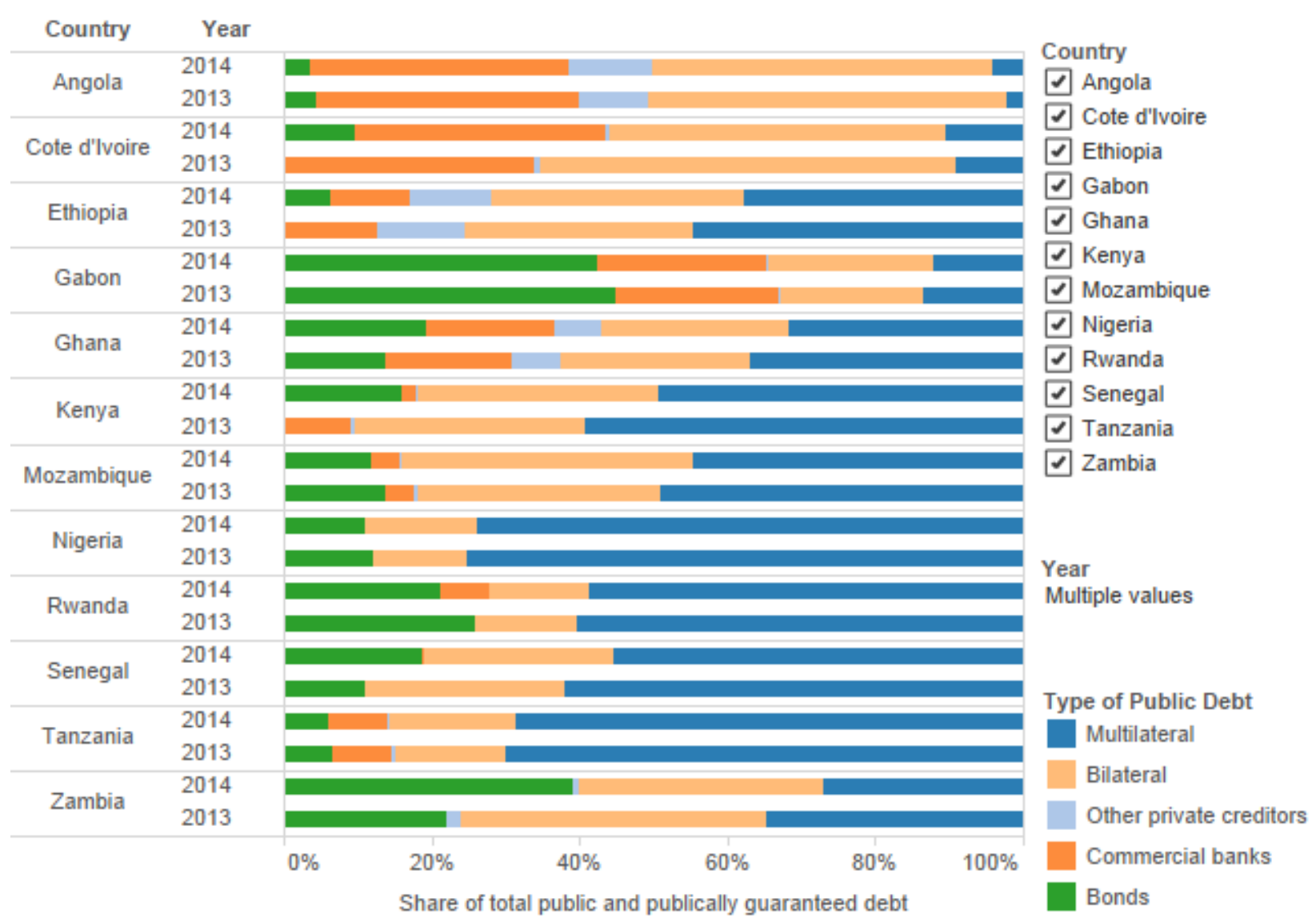

Figure 6. Selected Sub-Saharan African countries - Total public and public guaranteed debt by creditor (2013-2014)

Source: International Debt Statistics, the World Bank (2018)

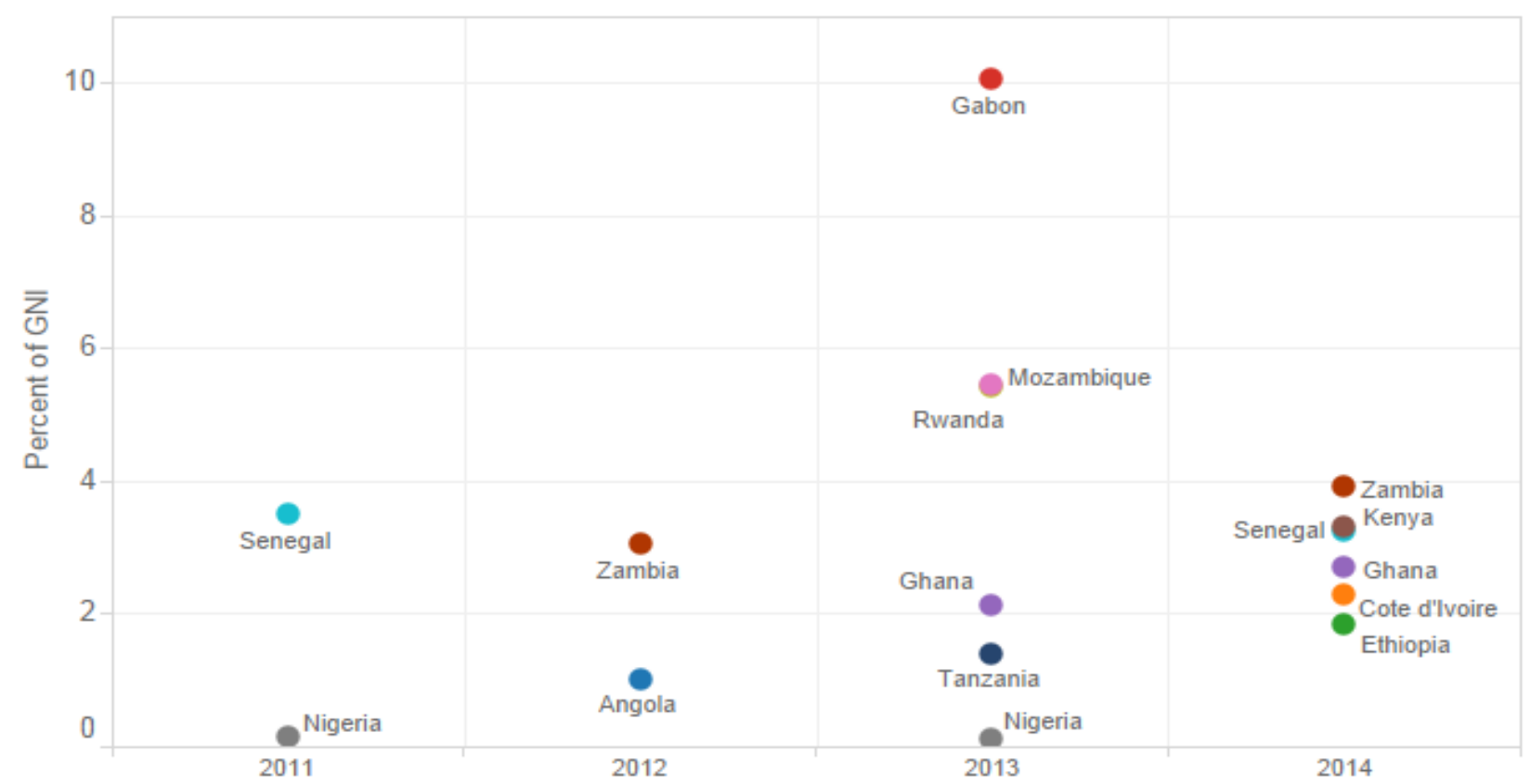

Figure 7. Selected Sub-Saharan African countries - Bond issuance as a percentage of Gross National Income (GNI), (2011-2014)

Source: International Debt Statistics, the World Bank (2018) 


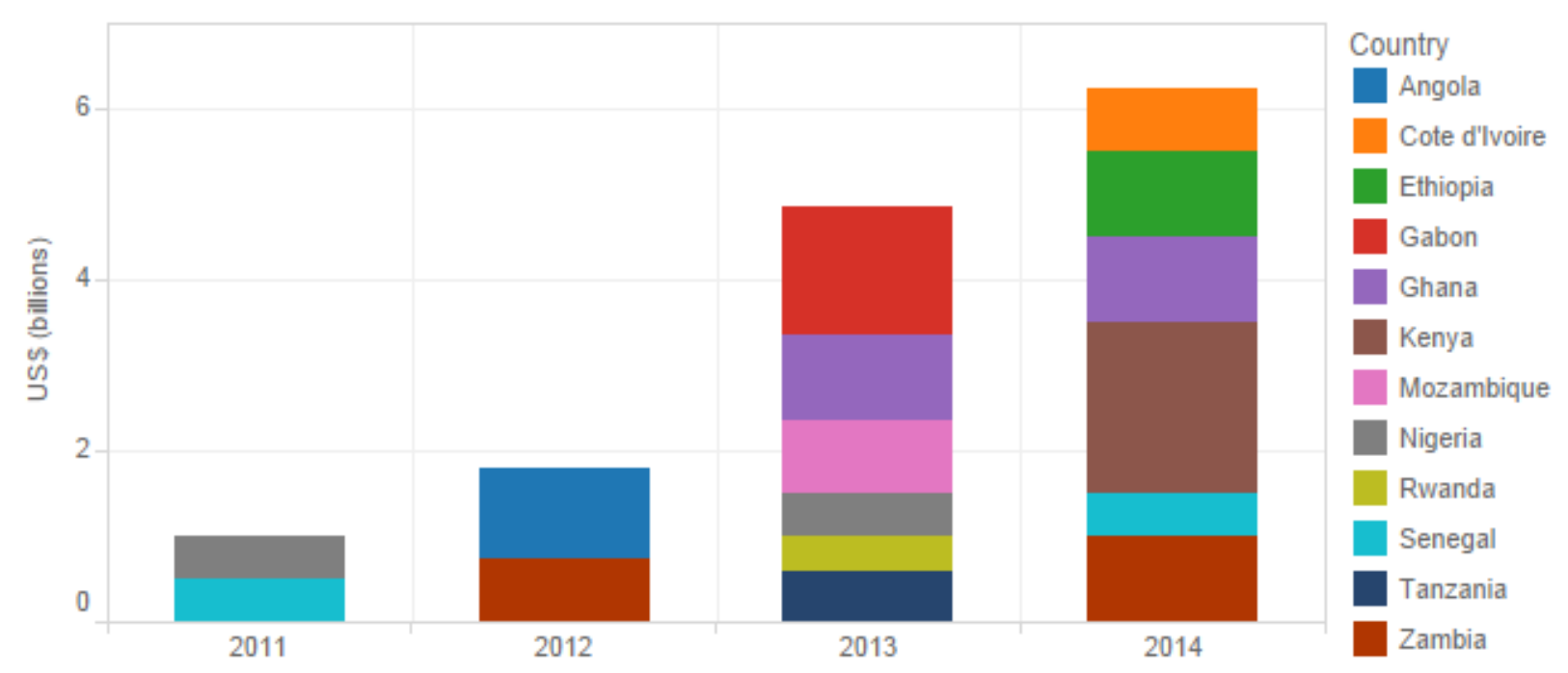

Figure 8. Selected Sub-Saharan African countries -Public and publicly guaranteed bond issuance bond (2011-2014)

Source: International Debt Statistics, the World Bank (2018)

Despite appealing prospects, there are imminent risks in SSA bond markets. Exchange rate risk and financial system fragility pose a big bottleneck in marshaling investor attraction to SSA bond markets (Tyson, 2015). Economic development is an agenda at the forefront of African governments. There is an increasing reliance on wealth funds, pension funds, private-public partnerships and bonds to finance nations' infrastructures. There has been less adequate exploitation of financing such projects through bonds (Figures 6, Figure 7 and Figure 8). Some of the reasons that need citing are weak secondary markets, weak institutional investor base and underdeveloped non-bank financial institutions. Some countries in SSA prominent in using bond finance are Nigeria, Uganda, Ghana, Cape Verde, Kenya and South Africa. These issues mainly are in forms of diaspora bonds to citizens living abroad, Islamic bonds issued under Sharia law, sovereign/external bonds, local issues of government bonds, corporate bonds, municipal bonds and agency bonds. Borrowing costs through bonds is lower than borrowing through loans. Bonds are a cheaper alternative to financing long-term infrastructure projects that governments in SSA should turn to.

Bonds in some selected SSA countries play significantly in financing national budgets (Figure 7). The bond market in South Africa is the most developed in Africa. Its secondary market is largely underdeveloped. The Republic of South Africa government bond finances the country's national budget and in some case infrastructures, for instance, in September 2008, the South African Road Agency issued 'domestic medium term note' (DMTN), six bonds (amounting to ZAR 850 millions) to finance the Gauteng Freeway Improvement Program, four of these were fixed rate with 20 years maturity. In March 2009, the Airports Company of South Africa issued domestically a bond valued at ZAR 1.1 billion. These and many other bonds are just examples of what bonds can accomplish in financing the African economies for the aspired development. Similar patterns are evident in other African Countries. The Nigerian bond market is another critical example, for instance between 1986 and 2012, 20 states in Nigeria have issued bonds to finance infrastructure projects within their states. The bonds issues mainly finance township and regional roads. By 2009, the Kenyan central bank had issued 68 treasury bonds. They have a combined value of KES 350 billion (Oji, 2015).

Some notable types of bonds are Diaspora bonds, Islamic bonds and Sovereign bonds. To finance the Grand Renaissance Dam the Ethiopian government issued a diaspora bond to its large diaspora who can trace their Ethiopian lineage to Ethiopia. The bonds were backed by revenue from the dam and the government. It was exempt from taxes. The diaspora bonds design to tap into the sentiments of the diaspora in pushing the development agenda of their own countries. However, other factors oftentimes outplay sentiments, for instance, security, risk and corruption in the countries issuing the bonds. Other notable examples of a successful diaspora bond outside of Africa are the Development Corporation for Israel bond. They were the pioneer in this type of bonds going back as 1951. It was registered with the US 
Securities Exchange Commission, its' interests were high above the US T-bills and as long as 20 years. This made the bonds very attractive and the Israel government was able to raise US\$ 32 billion with this bond's issue. India also issued a diaspora bond in 1991, 1998 and 2000 with 5 years maturity to finance balance of payment; it raised a total of US\$ 1.6 billion, US\$ 4.2 billion and US\$5.5 billion respectively. Depending on the perspective, the three bonds in these cases indicated some opportunistic characteristics to specifically finance some specific developments and as sources of capital for economic development of the concerned nations (Oji, 2015).

Islamic financing is enshrined in the sharia law. It is a substitute or complement to the western mode of financing. There is approximately 75 countries and 600 financial institutions that reached Islamic financial assets of US\$ 1.3 trillion in 2013 alone. Islamic financing prohibits interests on capital deposits and capital investments. This in turn lowers the cost of raising or borrowing capital. In this regard, Islamic bonds offer an opportunity to raise affordable development funds for countries with large Islamic population. Issuing Islamic bonds can help African nations to tap into the Islamic financial community and generate sufficient capital for infrastructure and economic development. Nigeria is one particular example where there is success in this angle. In September 2013, the Osun state in Nigeria issued and raised a seven-year Nigerian Naira (NGN) 11.4 billion Islamic bond for infrastructure development. Investors receive 14.25\% and $14.75 \%$ fixed return rates. Elsewhere in Africa, Gambia, Sudan, Kenya and South Africa, there are similar efforts underway to issue Islamic bonds. African countries need to look at this opportunistically by structuring such bonds to suits different potentials each country has in store. Other successful examples worth of emulating are for instance, the Middle Eastern countries that marketed their Islamic bonds to all people of the Islamic faith irrespective of their country of origin. These include Indonesia (US\$3.4 billion), Saud Arabia (US\$6.4 billion) and Malaysia (US\$31 billion) in 2012. The contribution of Islamic finance to economic development will depend on how bondholders will influence its direction. The supply factors currently influence Islamic finance, households in some SSA countries play role in the demand side, and there is low involvement of government and private institutions. It is worth noting that, the success of Islamic finance in bolstering economic development depends primarily on the implementation of innovative mix of products, adequate governance mechanism of Islamic law and institution of Islamic finance intermediaries (Ahmed et al., 2015). If good design are available Islamic finance will play a big role in mobilization of domestic finance (Ahmed et al., 2015) as well as external finance.

Sovereign or external bonds are bonds guaranteed and sold by their respective governments issued in foreign currency and sold to foreign investors. Some examples include Ghana in 2007 issued a 10 year US\$750 million bond through international capital markets to finance development agenda in Ghana. It aimed at financing Ghana's energy and transport infrastructure development projects. In 2013 Rwanda issued a 10-year US\$400 million external bond with interest set at $6.875 \%$. The aim of the bond was to finance a hydroelectric power among other development needs. Some more countries that have issued are Gabon, Nigeria and Zambia, others planning to move towards this direction are Tanzania and Kenya (Oji, 2015).

Given the low level of development in stock markets (Figure 4) and particularly bond markers in Africa and less liquid and underdeveloped secondary markets (Figure 5), African nations need to harness through desirable characteristics from their financial markets environment. Some of these aspects are issuing bonds that fit into certain African interests and sentiments. For instance the general African diaspora, the Islamic diaspora, the Swahili language diaspora (for countries speaking Ki-Swahili), the AfroAmerican diaspora for Afro-Americans who have a burden for African development. Bonds issued along those characteristics may raise funds essential to finance inter-country or regional investments and infrastructures. The degree of market integration and cooperation can feature through bond issues for specific cooperative investments. The international bond markets are other sources of funds that can benefit the African countries. Currently the outstanding private debt securities are still low in SSA (Figure 9). Emulating efforts done by for instance Ghana and Israel through issues of sovereign and diaspora bonds SSA can finance their development agendas. Some other take-home lessons are inculcating an investment and saving culture among African households, improving on trading regulations, upgrading the clearing and settlement systems, establishing rating agencies and developing secondary markets to allow holders 
options to trade their bonds before maturity. There is a need to decentralize governments in Africa. One way is to empower local government authorities through their municipalities.

Therefore, the development of bonds markets could be augmented by introduction of municipal bonds. The funds raised by these bonds need to be invested within respective municipals. These bonds create transparency, accountability and development to the municipalities. They will easy the need for central government budgets and create a sense of ownership of development projects at that level. Like in other countries such as USA which established the Municipal Securities Rule Making Board. It oversees fair practices for underwriting and issuing municipal bonds. There is also a need to move from general obligation bonds to revenue bonds. This ensures that projects financial and economic feasibility of issuers back the actual value for trade for these bonds rather than backing up these bonds by government guarantees through tax regimes. Oji (2015) indicates that this has been a trend and shift in USA and Mexico municipal bond markets development, a feature that is not prominent in African bonds markets. In most African bonds, the bond issues are not specific to financing projects or infrastructures. They are generalpurpose bonds. They have not income streams attached to constructing underlying assets such as toll roads, dams, bridges, airports, seaports or solar farms. On another level, Tyson (2015) notes that challenges in exchange rates volatility and financial system fragility call for policy address on such aspects as regional common currencies, debt management capacity, sound macroeconomic management, capital flow management and strong government actions against corruption and financial legal reforms.

In China, local governments play essential role in public finance and fiscal policy. They play a vital role in regional developments and services provision. They account for over $50 \%$ of general government revenue and over $80 \%$ of general government expenditure. China's government bond market is the largest in the world. It grew rapidly over a decade, from RMB 1.1 trillion to RMB 14.7 trillion, between 2014 and 2017. Nevertheless, its bond market is underdeveloped in terms of its infrastructure and liquidity levels. The central government allows local government to issue bonds within a certain cap to help finance local governments. The central government of China secures the local government bonds. Wealthy provinces have more debt but lower debt per GDP comparing to poor provinces. Currently, 37 out of 53 major economies permit local government to issue bonds (Lam and Wang, 2018). Understanding the role of local government in a country may inform African economies on how they should structure their municipal or local government bonds. Following the Chinese examples, African economies should issue local government debt to finance local government infrastructures and projects. Some lesson to lean from China include matching local government bonds issuances with general liquidity and infrastructure development in bond markets both at the central government and local government levels. Some comparable issues in Africa that need addressing are narrow investor base that leads to low debt demand, poor credit discipline that may lead to moral hazard and poor risk pricing, low liquidity that is due to lower trading volume and unharmonious regulations which dispels investors' confidence and creates room for price distortions. Others includes limited awareness, knowledge and debt management capacity at local government levels, which is essential in monitoring risks, matching bond financing to development projects. Grigorian (2019) indicates factors that foster development of debt markets, which can apply at local government levels, include appropriate legal foundations, vigorous fiscal and structural policies, and monetary policies that ensure well-monitored inflationary expectation and a more freely floating exchange rate that pulls investors in.

Following the Chinese experience and the ideas of Lam and Wang (2018), African economies may design their local government and central government bond markets with the following in their agenda; the design should aim at broadening the investor base and improving liquidity. This entails, developing harmonious and relevant regulations that will safeguard against market segmentations. Design better market making and trading arrangements for securities brokerage, design standard terms for trading, settlements and trust methods that will enhance market predictability, design real-time trade data in the secondary market that allows mark-to-market valuation. The level of central government decentralization on this agenda needs attention. This entails central government design and delivery of policies and design of decentralization to a level that will create accountability in the local government that will issue bonds. Timely disclosure of local government finance that will inculcate oversight and credit discipline of investors. The establishment of specialized debt management trust at both local government and central government 
levels. For instance, in USA the U.S. Securities Exchange Commission handles approval of municipal issuance and sets disclosure requirements, while the Municipal Securities Rulemaking Board manages municipal debt issuance.

Grigorian (2019) notes that the Malaysian local currency debt market is one of the most-liquid public debt markets in the world. Compared to other regions, while there is high need for funds to finance investments, SSA outstanding public debt securities are low (Figure 9). Policy agenda need to focus on improving the issues and address factors higher utilization of this mode of financing. Malaysia is the main home for Islamic debt instruments such as Islamic bonds. The country benefits from a successful implementation of robust regulatory reforms in 2000/2001. The market is currently a consistent source of finance for both private and public sectors. Nonresident debt holders characteristically dominate it. A wellfunctioning local currency public debt market largely ensures stable budget financing and enhances financial deepening and economic development. SSA needs to improve its' public debt low rates to take benefits from the aforementioned advantages (Figure 8). The role non-resident-investors play in developing debts markets in emerging and developing countries is very crucial. They diversify local market investor base; they enhance deeper liquidity and they reduce the direct link between local institutions with the government thereby increasing independence from the government. While bond issues positively influence non-resident capital flows, inflation and foreign exchange volatility negatively affects non-resident capital flows. Therefore, designing successful sovereign bonds need to take on board these issues.

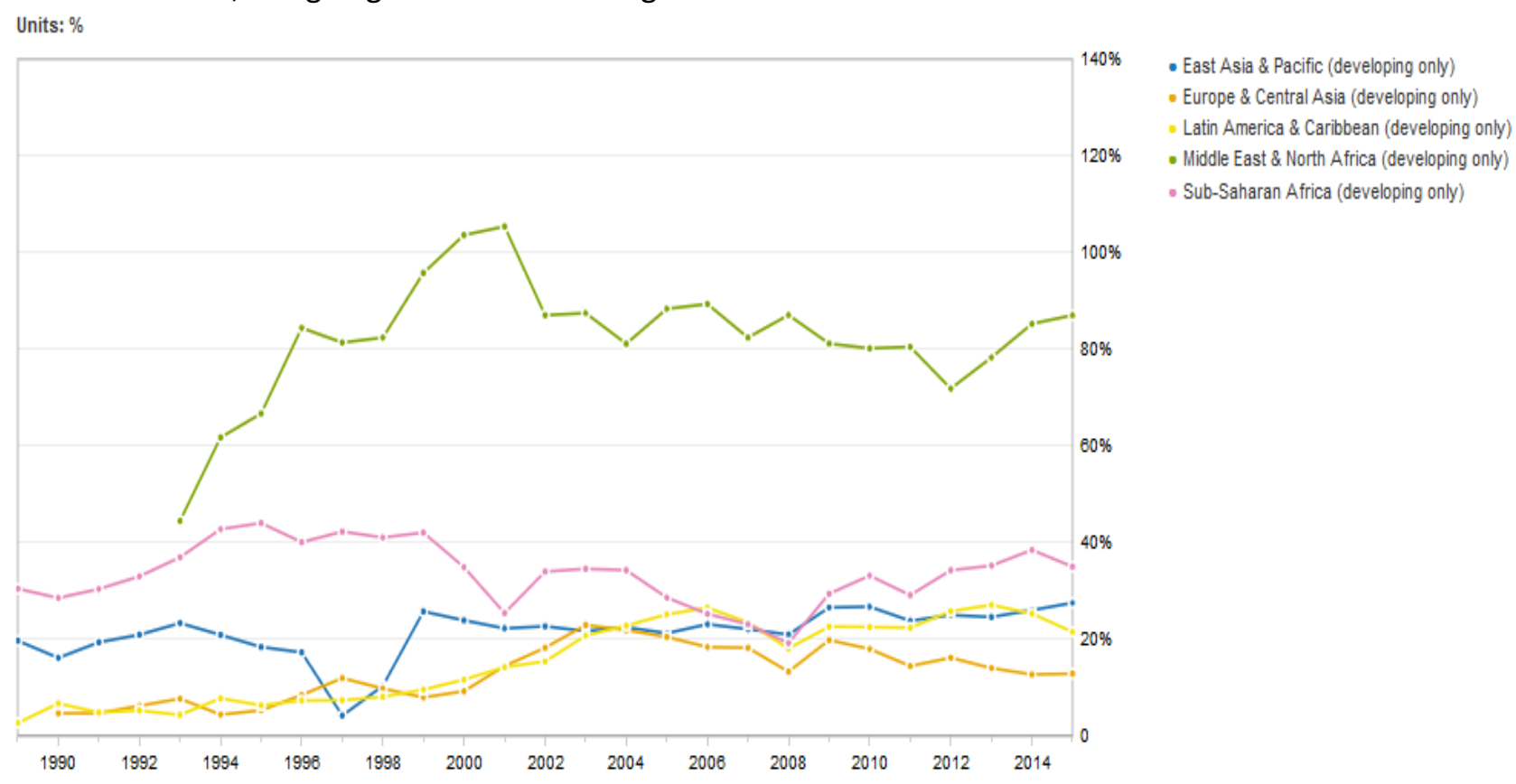

Figure 9. Comparable regions outstanding domestic public debt securities to GDP (\%). (I.e. It covers longterm bonds and notes and money market instruments placed on international markets)

Source: World Bank (citing, International Financial Statistics (IFS), International Monetary Fund (IMF)) (July, 2018)

\subsection{African banking modes and reforms}

The banking system plays a resource mobilization and allocation function like no other in the financial system (Bumann et al., 2013). It comprises the most developed part of the financial system in African economies. Banks if rightly tuned may function as source of financial innovations and efficiency. But if wrongly tuned, it may as well play a source of systemic risk in the financial structure via contagion effects. The dominance of the banking system in African financial system is susceptible to banking ubiquitousness (Moyo et al., 2014). Such undiversified position of the financial system can easily lead to systemic bank failure. Notably, the SSA financial system is broadly bank based; any systemic failure in the economy would result into serious consequences in these economies. The SSA banks are both big or small in their own financial system and small abroad. The stock of bank credit and private debt securities to the private sector 
is low when compared to other developing countries (Figure 10). This reflect low level of financial intermediation due to less development in the financial system.

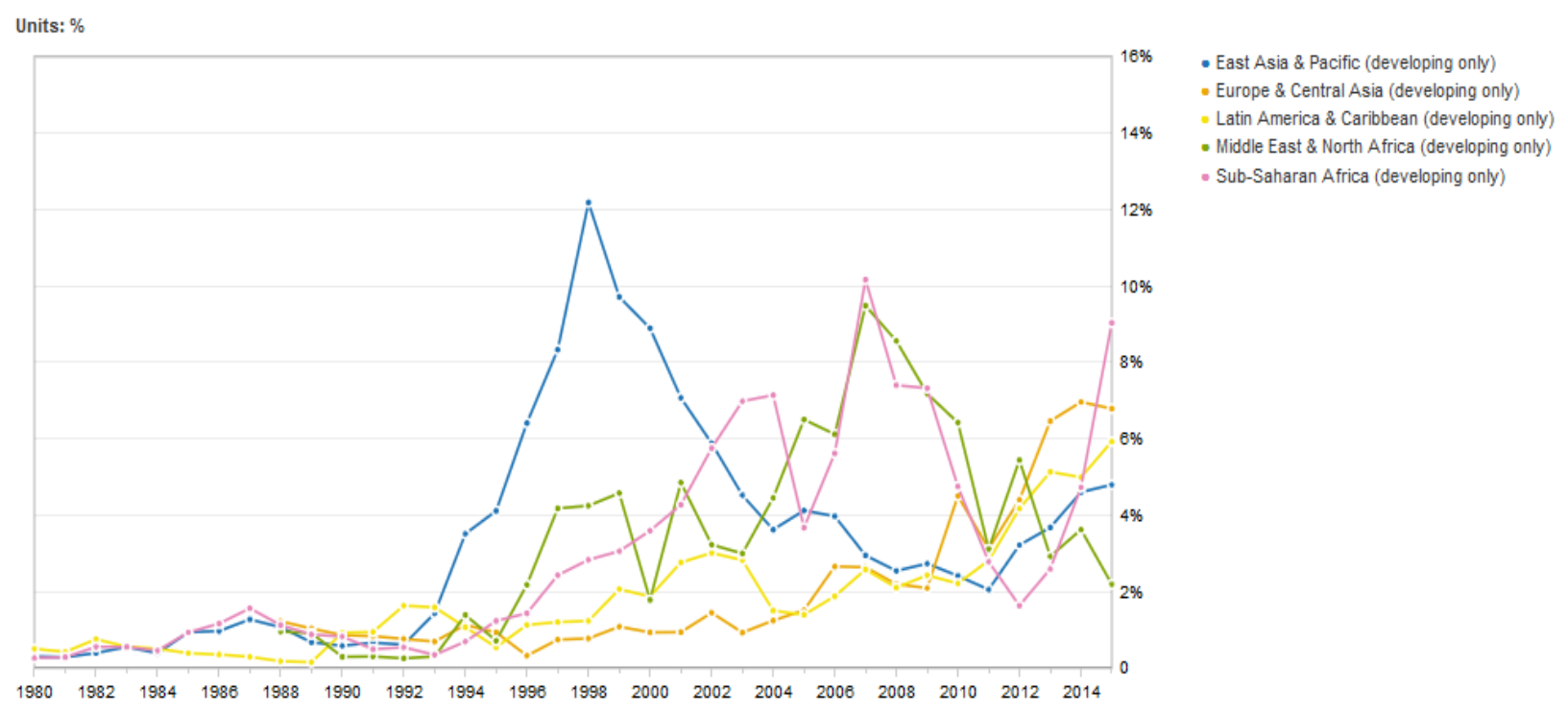

Figure 10. Comparable regions outstanding international private debt securities to GDP (\%). (I.e. Amount of private international debt securities (amounts outstanding), as a share of GDP. It covers long-term bonds and notes and money market instruments placed on international markets)

Source: World Bank (citing, International Financial Statistics (IFS), International Monetary Fund (IMF)) (July, 2018)

Faster economic growth is not possible where there is no corresponding deepening of the financial system particularly through the banking sector. The major banking concern in SSA relates to the inability of banking systems to allocate resources through credits to small and medium enterprises (SMEs), new economic initiatives and agricultural projects (Sacerdoti, 2005). How to qualify these sectors to receive such needed funds is currently a big concern as they are yet risky areas. While microfinance institutions (MFIs) have tried to penetrate these sectors, their channeling sizes are small and highly costly due to high-risk profiles in these sectors. Some related issues particularly that need attention include but not limited to banking sector fragility, competitiveness, efficiency, liquidity and level of inclusion.

Over more than two decades now, SSA has embarked on banking reforms and restructuring. Some are privatization, liberalization and increasing the share of the private sector in the financial system. To some extent, this has led to mobilization and allocation of resources that needed channeling yet. On a quick historical note, Sacerdoti (2005) indicates that reforms in SSA are not very old for instance; Senegal in 198889, Côte d'Ivoire 1988-89, Benin 1988-89, Mali 1989, Niger 1989-90, Nigeria in the late 1980s, Cameroon 1990-97, Kenya 1993-94 and 1998, Madagascar 1996-98, and Tanzania 1996-99. The restructuring process is continuing in Kenya, Tanzania, Zambia, and more reforms need to happen in this sector.

The banking system is highly regulated based on regulators' choices as such it is less diversified compared to other sectors. Legal and institutional frameworks have barred banks from assuming big risks and channel funds to less credit recipients. Relaxing on diversification, legal breaks and flexing institutional expansion through acquisition and amalgamation may lead to both covering for the feared high risk and channeling large funds to the needy sectors that would otherwise not qualify. The SSA banking system need to experience size effects that will efficiently spearhead the needed economic growth. Agricultural and small and medium enterprises (SMEs) financing, highly emphasized in SSA countries faces serious failures. Most agricultural banks have failed and microfinance institutions (MFIs) have failed to offer credits at affordable rates. The costs of running business in SSA have consequently always been high and the agricultural sector very less financed. Some reforms are needed in areas that led to this position, for instance reform on land tenure system to allow for land collaterals, facilitate physical collaterals by linking financing to mechanization of agriculture, the link between banking and cooperative farming need to be more reformed and established. The role of banking system to economic growth partly depends on a sound legal framework that ensures both full ownership and full control of land and other properties. The reforms 
on ownership and control are in its nascent stage, thus more need to be done. For instance, in Tanzania, land act reforms started in 2004 to promote collateralization, in Mozambique and Madagascar there are restrictions on use of land as collateral, in all three countries the legal, process and enforcements are both slow and lengthy. In Kenya during the late 1970s, 1980s and early 1990s, policy reforms were introduced to liberalize the banking sector and empower institutional frameworks. During the same periods, stock market reforms have included regulatory, judicial, legal and governance mechanisms (Nyasha and Odhiambo, 2015).

Economic developments emanating from non-financial sectors play a significant role in influencing financial development. There is a mutual causation between financial development and economic development. In developing countries for instance Kenya (Nyasha and Odhiambo, 2015), the non-financial sectors drive banking sector development. The 'finance-led growth hypothesis' contends for the role of financial development in driving economic development. The crunch of the matter points to the conclusion that, finance-led growth is possible at a certain high level of development. Policy in the SSA context needs to address the needs of non-financial growths, encapsulated in the 'growth-led hypothesis' which contends that economic development drives financial development. When non-financial development occurs up to a certain level. The two aspects will eventually shift positions, so that the financial sector growth will affect non-financial sectors growth. This is possible if the non-financial growths are already experiencing some level of development in SSA. On another feel, the bidirectional or feedback hypothesis postulates for a mutual causation that occurs concurrently between financial development and economic development. This possibility has been the most sought in SSA. As noted earlier, SSA financial systems are predominantly bank-led rather than market-led. The latter mode is considered too sensitive to movements and shocks in the economy, whereas there is more stability in the former mode. The market led financial system potentially provides a broad set of risk amelioration strategies and options. It has more capacity to influence economic development than it is for the bank-led financial system (Nyasha and Odhiambo, 2015). Thus, as economies mature, they tend to move from bank-led economies to market-led economies. SSA is yet to see this transition. Some notable findings as documented by Nyasha and Odhiambo (2015) indicate that investment and bank-led financial development have mutual causation on each other. There is no causation between investment and market-led financial development. These results' lessons are particularly relevant to developing and emerging economies in SSA.

Lack of long-term finance is a major challenge to both corporation and government in developing countries since the global financial crisis of 2008/09. Long-term finance if available allows them to finance large and long-term investments (Peria and Schmukler, 2017). It is known that short-term financing dominance led to well-known financial crisis around the world. As a result, scholars emphasize long-term borrowing (Beltratti and Stulz, 2012; Broner et al., 2013; Peria and Schmukler, 2017). Long-term finance is optimal in some situations while short-term finance is suitable and optimal in some situations. In case of reducing interest risk, governments and firms alike prefer long term-finance. Risks if are not ameliorated they generate economic costs. In absence of long-term finance firms resort to short-term finance in which case they may curtail their investments or exit. To the economy, long-term finance is likely to contribute to economic growth and dissipate macroeconomic volatilities. For governments, long-term finance is crucial for infrastructure investment and other long-term investments, which otherwise short-term finance cannot support. Some notable feature of developing economies is that long-term finance in developing economies is more limited than in developed economies. Banks are the most important sources of finance. Banks offers mostly short-term finance. Financial markets are only accessible to small groups of firms and are less developed. Domestic institutional investors have a low participation in the financial markets. Bank loans maturities are short when compared to bank loan maturities in developed economies. Research shows that macroeconomic factors such as low inflation, strong institutions, level of financial sector development, effectiveness in financial contracts enforcements and credit information landscape lengthen bank loans maturity. Bank size positively correlate with loans maturity. Surprisingly also, dominance of state-owned banks reduces loans maturity, while dominance of foreign banks has higher likelihood of issuing loan with long-term maturity. Banking regulations that limit bank size and capitalization are likely to reduce longterm loan maturities (Peria and Schmukler, 2017). SSA needs policy reform in the banking sector. The following can be considered; promotion of strong institutions, macroeconomic stability, liberalization of the 
banking markets, expansion of the private sector and legal reforms on land collaterals and enforcement of contracts.

\subsection{Enhancing financial deepening, inclusion and reforms}

Financial deepening refers to the increase in financial assets (such as bonds, stocks and bank deposits) to the economy's GDP. Within the SSA comparable regions, deposit money bank assets to GDP rates are low hitting only a maximum of about $21 \%$ in 2015 compared to about $68 \%$ for developing Latin America and Caribbean counties and about 70\% for North Africa and Middle East countries (Figure 11, Figure 12 and Figure 13).

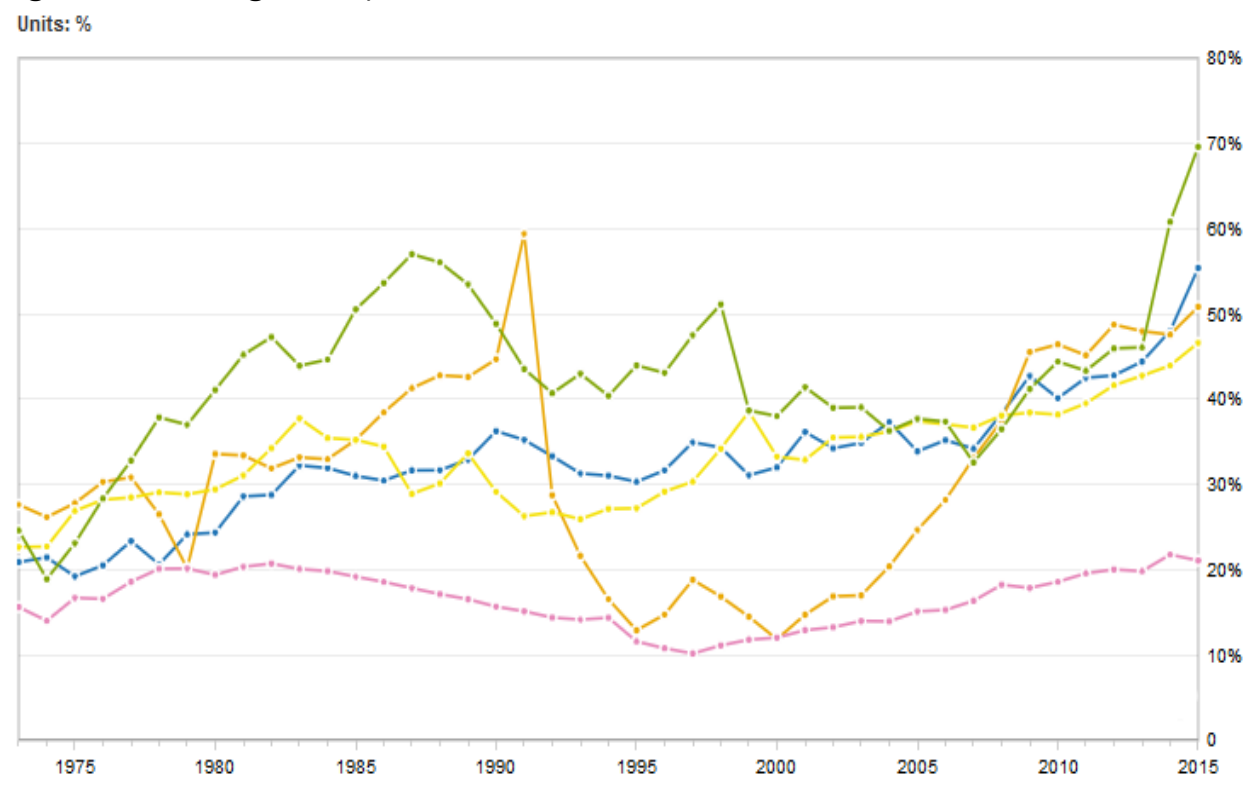

- East Asia \& Pacific (developing only) - Europe \& Central Asia (developing only)

- Latin America \& Caribbean (developing only)

- Middle East \& North Africa (developing only)

- Sub-Saharan Africa (developing only)

Figure 11. Comparable regions deposit money bank assets to GDP (\%). (I.e. Claims on domestic real nonfinancial sector by deposit money banks as a share of GDP)

Source: World Bank (citing, International Financial Statistics (IFS), International Monetary Fund (IMF)) (2018)

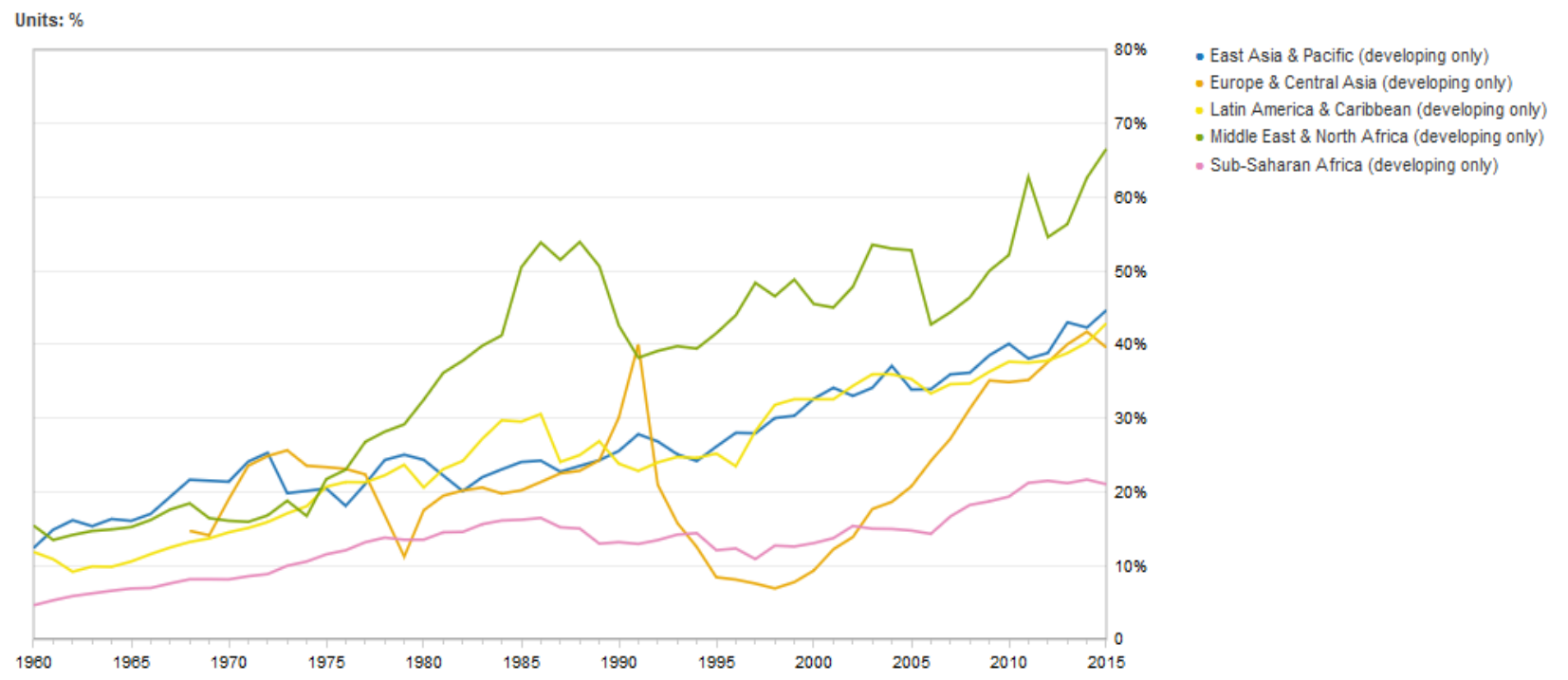

Figure 12. Comparable regions bank deposits to GDP (\%). (I.e. Demand, time and saving deposits in deposit money banks as a share of GDP)

Source: World Bank (citing, International Financial Statistics (IFS), International Monetary Fund (IMF)) (2018) 


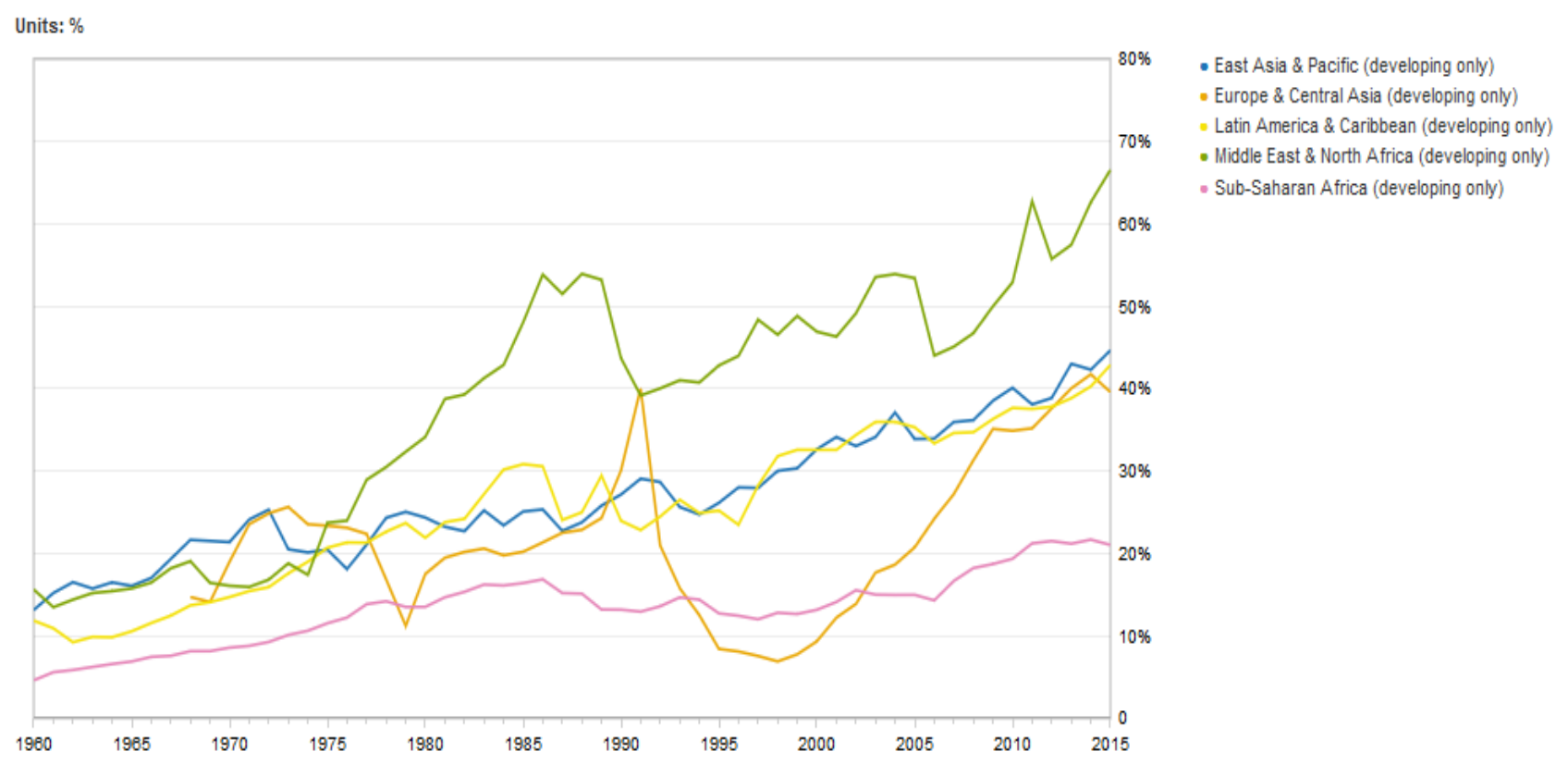

Figure 13. Comparable regions financial system deposits to GDP (\%). (I.e. Demand, time and saving deposits in deposit money banks and other financial institutions as a share of GDP)

Source: World Bank (citing, International Financial Statistics (IFS), International Monetary Fund (IMF)) (2018)

Financial inclusion is the spreading of financial services across economic agents such as firms or and households. There are demand side and supply side views on conceptualization of financial inclusion. The demand side captures shares of household or and shares of firms access to financial services. The supply side captures bank branch density, number of ATMs and mobile banking penetration (mobile phones). Financial inclusion affects economic agents' growth and or growth positively. The impact is high where bank markets are less concentrated. High bank competition grows hand in glove with firm growth at high financial inclusion. Generally, a strand of literature directs that financial development enhance innovative and productive investment projects; it reduces costs of transaction, increase capital allocation efficiency and management of risk. Financial deepening effects on growth depend on levels of financial inclusion. It lowers constrains on liquidity and stimulate investment (Chauvet and Jacolin, 2017).

Bank concentration refers to banking market structure. The measure of bank concentration is market share of the two or three largest banks, decreasing the number implies reducing the intensity of concentration at which we are measuring its' concentration. Bank concentration may favor financial inclusion and banking market efficiency. Bank concentration in emerging and developing economies positively influences firm performance when financial inclusion stoops low. Financial inclusion positively boosts firm growth, while bank competition (i.e. lower bank concentration) fuels the impact, suggesting complementarity between financial inclusion and bank competition. Bank concentration does favor performance of firms in emerging and developing economies. More specifically, financial inclusion is crucial in less developed economies, when financial inclusion declines low and bank concentration ascends high (Chauvet and Jacolin, 2017).

Evidence where financial development may likely promote economic growth and stability (Ikhide, 2015). New search for the link seems promising by looking at the effect that financial inclusion has on financial development and ultimately triggers on economic development particularly in Africa. Improving microfinance institutions will bootstrap to financial inclusion and consequently promote economic development. Financial inclusion to be of real value to the economy must embrace around core elements of financial intermediation such as asset transformation, savings mobilization, risk amelioration and espousing monitoring, control and efficiency. Policy agendas on financial inclusion should address the whole intermediation space rather than stick on transactions only. The following issues must inform the policy agenda themselves. The mere creation of financial access for inclusion may not lead to financial 
deepening and economic development. It is worth noting that effective supervision and regulations promote financial development and stability. Policies in most African states emphasize financial inclusion, but some shortfalls in these policies have less emphasis in microfinance institutions and must compass the complete financial intermediation archetype (Ikhide, 2015). On effects of financial development on economic development seems to shrink mainly due to financial crises and crushes. The measures used to proxy financial development indicate varying sensitivities (Ikhide, 2015). Ratios based on GDP and ratios based on total credits for instance yield positive effects that are economically large as well (Adu et al., 2013). However, most of African economies are on favorable range.

\subsection{ICT driven financial information sharing and reforms}

The success of mobile banking and the use of ICT in financial markets in Africa play an important role in enhancing financial depth and financial transactions. ICT driven financial information facilitates money supply and facilitates liquidity. It expedites financial activities at banking levels and at financial markets levels. It lubricates efficiency of financial intermediation processes. It also increases the level of financial inclusion size (Asongu et al., 2017).

Unlike in most European, American and Asian countries, African countries have higher potentials for ICT development. African countries have unsaturated potentials for ICT growth and development. Policy mechanisms can address this penetration potential for developmental agenda particularly increasing financial access among other contextual African financial system limitations. Evidence shows that less than $20 \%$ of the households in Africa access formal financial services (Asongu et al., 2017). The informal financial systems play a role for the rest of the population. It is characteristically at places dispersed, with poor connectivity and poor transportation, low literacy and less ability to meet credit documentation requirements due to information asymmetry between financial institutions and lenders. This background coupled with high transaction costs significantly limit access to financial services in Africa. Currently some African economies are employing information sharing centers. These are public credit registries and private credit bureaus. Particularly, Asongu et al. (2016) deduce that these bureaus and registry have negative impacts on financial depth and financial activity. Notably, private credit bureau has negative impacts on banking system efficiency. As a way to ameliorate the situation, ICT penetration do play and may much more play a critical role in information sharing. This will dissipate asymmetry information quandary, namely its' cost and risk evils. It will increase credit and market competition, lower credit constrains and improves capital allocation. On another level, ICT facilitates availability of timely and comprehensive information on borrowers' history, monitor and manage borrowers' credits, reduce both adverse and moral hazard problems. Information sharing through ICT has the potential of increasing allocation efficiency by dissipating channeling costs of mobilized funds to lenders from borrowers (Asongu et al., 2016, Asongu et al., 2017).

Asongu et al. (2017) commend the African experience in that their evidence indicate that African financial institutions are taking advantages of ICT-driven information sharing centers. These centers improve financial access in the continent and increase financial institutions profit margins. The centers also arguably stimulate competition, increase financial activities, reduce financial restrictions, reduce surplus liquidity in the financial system, dissipate big banks market power abuse through reduction of information cost and increase contestation for credit markets. They further adjoin the acclaimed fact that less access to finance poses a big challenge to doing business in Africa. They have been able to show that ICT driven information sharing if implemented to its potential would increase financial access in Africa. With this in mind, it is reasonable to point out that, all been equal finance may promote growth but inclusive finance promotes quality economic growth. On a policy level, information sharing increases financial depth (deposits), financial activities (credits), and allocation efficiency (transformation of deposits into credits). Policy reforms need to invest more in ICT for financial system development.

\subsection{International financial integration in Africa}

International financial integration involves both quantity measures, such as cross boarder lending, non-domestic shareholdings and price measures, such as dispersion in asset returns in an economic region. A converging trend signals increasing integration. It implies that economic regional factors more influence 
asset returns rather than country specific factors. For examples narrowing dispersion of interest rates on credits, mortgages and deposits indicate increasing banking financial integration in an economic region (Zhang and Matthews, 2019). Edison et al., (2002) find positive but marginally significant effects of total capital outflow and total capital inflow as indicators of international financial integration measure on economic development. The growth-international financial integration relationship becomes stronger in counties with low level of development. A case to consider is the ASEAN region, whose founding members are Thailand, Malaysia, Indonesia, Singapore and the Philippines. The five economies together make for $87 \%$ of total ASEAN GDP and $73.51 \%$ of the total ASEAN population. This market is one particular case where some co-integration studies for convergence have found partial or short-term financial integration. In the ASEAN market, there more evidence for increasing convergence since the 1997 Asian crisis (Zhang and Matthews, 2019). Evidently, financial integration through financial variables convergences such as market or bank competitiveness and interest rates lead to increased financial pooling capacity, increased financial allocative efficiency, increased financial channeling capacity, reduced prices on financial services and credits. Financial integration on another level protects an economic region from external financial and economic shocks. It also fosters financial stability and competitiveness within an economic region.

Financial systems integration is not a new phenomenon in Africa. The Middle East and North Africa (MENA) stock markets serve an excellent example. Studies have found rather a strong integration between the less developed markets for instance the MENA capital markets (i.e. Morocco, Egypt, Jordan and Turkey) and developed markets (e.g. United States, United Kingdom and France). However, they found weaker integration among MENA capital markets themselves (Garali and Othmani, 2015; Neaime, 2002). More research needs to feed policy to this ambiguous situation. Financial systems integration at different level and mode is significant; African economic regions may achieve it at the level of financial markets and level of banking industry among others. Some notable issues on financial system integration that accumulated through research include, lowering capital controls and other restriction on capital accounts, foster financial integration that promotes economic growth. Trade openness positively affect foreign debt. The level of economic development enhances international capital flows, financial development arguments more opportunities for economic argents, lower exchange rate volatilities and lower inflation rates promote local investments and international financial integration (Garali and Othmani, 2015). Policies agenda need to focus on these issues to improve integration at various African regions such as East African Community (EAC) and Economic Organization of West African States (ECOWAS).

Garali and Othmani (2015) specifically posit that there is a positive effect from level of financial integration to economic growth. Financial integration is beneficial to member economies when the following are re-aligned; economic policies for financial sector development, enhanced institutional quality, improved trade openness within and among economies in a region of integration. Therefore, Africa need to open up capital controls for financial integration to boost investments in its economic regions. It needs to redress its economic policies on financial sectors development and integration particularly on lending policies and investments policies.

Financial integration in the African landscape saw the advent of increasing footprints of African banks. Cross-border banking is an issue of increasing importance in Africa. The financial systems in African stand to gain more from cross-border banking. Given the smallness of financial markets in Africa, economies await to gain more from cross-border banking. However, this aspect hinges on financial infrastructure and its information sharing capacity, the dominating government owned banks market structure, harmonization of regulatory policies and laws to hasten integration. One obvious hindrance is the presence of rudimentary banking system in Africa. To take advantage of financial integration via banks, countries that share close ties need to prioritize strengthening their mutual financial infrastructure. Some areas that may need attention are improving comparability of credit information across countries, speeding payments systems efficiency and imparting financial literacy. The role of ICT infrastructures and risk management skills if improved play crucial roles in deepening, competition, innovation and saturating the intermediation role of banks. Consolidated supervisions, cross-border information flows and exchange, resolution frameworks are green areas whose improving will lead to cost savings. Integrated banking modes should include reducing licensing complexities, reducing minimum capital requirements for subsidiaries; encourage labor mobility and use of centralized ICT platforms. Integrating mobile banking and 
on-line banking across regions is also important. Harmonization of the regulatory environment will contribute to certainty in regards to operation consistency and predictability and reduce compliance costs. Convergence of policies, banking laws, and banking practices will reap more on banking to the economies (Beck et al., 2014).

\section{Conclusions}

Financial systems play roles in economic development. Africa has not fully developed its financial systems. They can be improved to function for the enhancement of economic development by considering the following policy agendas. Improving financial inclusion at all levels of financial intermediation. Liberalizing the economies, attracting foreign investors and promoting local investors involvement. Strengthening the legal and contracting frameworks into enforceable financial contracts. Harmonizing regional banking systems to tap into financial integration essential in handling bulky financing. Integrating ICT and information sharing in the financial system development agenda. Decentralizing the financial system to its municipal levels where municipal bonds issuance may be financed by municipal bonds revenues, this will create source of local funds, ownership and effective control, accountability and management of the development projects. Diversifying the bank dominated financial systems by expanding the non-bank segments of the financial systems; these may include the stock markets, bond markets and micro financing. More research needs to be conducted with an African focus unique to the continent and specific policies be addressed within these proposed policy agendas.

\section{References}

1. Adu, G., Marbuah, G., and Mensah, J. T. (2013). Financial development and economic growth in Ghana: Does the measure of financial development matter?. Review of Development finance, 3(4), 192-203.

2. Ahmed, H., Mohieldin, M., Verbeek, J. and Aboulmagd, F., (2015). On the sustainable development goals and the role of Islamic finance. The World Bank.

3. Asongu, S. A., Anyanwu, J. C., and Tchamyou, V. S. (2017). Technology-driven information sharing and conditional financial development in Africa. Information Technology for Development, 1-30.

4. Asongu, S., Le Roux, S., Nwachukwu, J. and Pyke, C. (2019). Reducing Information Asymmetry with ICT: A critical review of loan price and quantity effects in Africa. International Journal of Managerial Finance, 15(2), 130-163.

5. Beck, T., Fuchs, M., Singer, D., \& Witte, M. (2014). Making cross-border banking work for Africa. Eschborn, Germany: Deutsche Gesellschaft für Internationale Zusammenarbeit (GIZ) GmbH.

6. Beckmann, E., (2019). Household Savings in Central Eastern and Southeastern Europe: How Do Poorer Households Save? (No. 8751). The World Bank.

7. Beckmann, E., Reiter, S., \& Stix, H. (2018). A geographic perspective on banking in Central, Eastern and Southeastern Europe. Focus on European Economic Integration, (Q1-18), 26-47.

8. Beltratti, A., \& Stulz, R. M. (2012). The credit crisis around the globe: Why did some banks perform better?. Journal of Financial Economics, 105(1), 1-17.

9. Bhushan, A. (2013). Domestic resource mobilization and the Post-2015 Agenda. Great Insights, 2(3), 22-23.

10.Broner, F. A., Lorenzoni, G., \& Schmukler, S. L. (2013). Why do emerging economies borrow short term?. Journal of the European Economic Association, 11(suppl_1), 67-100.

11.Bumann, S., Hermes, N., \& Lensink, R. (2013). Financial liberalization and economic growth: A meta-analysis. Journal of International Money and Finance, 33, 255-281.

12.Chauvet, L., \& Jacolin, L. (2017). Financial inclusion, bank concentration, and firm performance. World Development, 97, 1-13.

13.Deltuvaitè, V., \& Sinevičienè, L. (2014). Investigation of relationship between financial and economic development in the EU countries. Procedia Economics and Finance, 14, 173-180.

14.Fung, M. K. (2009). Financial development and economic growth: convergence or divergence?. Journal of international money and finance, 28(1), 56-67.

15.Garali, W., \& Othmani, S. (2015). The determinants of international financial integration in the MENA area. Procedia Economics and Finance, 26, 535-541. 
16.Grigorian, M. D. A. (2019). Nonresident Capital Flows and Volatility: Evidence from Malaysia's Local Currency Bond Market. International Monetary Fund.

17.Ikhide, S. (2015). The finance and growth debate in Africa: What role for financial inclusion. University of Stellenbosch Business School.

18.Karlan, D., Ratan, A. L., \& Zinman, J. (2014). Savings by and for the Poor: A Research Review and Agenda. Review of Income and Wealth, 60(1), 36-78.

19.Lam, W. R., \& Wang, J. (2018). China's Local Government Bond Market. International Monetary Fund.

20.Mitchener, K. J., \& Wheelock, D. C. (2013). Does the structure of banking markets affect economic growth? Evidence from US state banking markets. Explorations in Economic History, 50(2), 161-178.

21.Moyo, J., Nandwa, B., Council, D. E., Oduor, J., \& Simpasa, A. (2014). Financial sector reforms, competition and banking system stability in Sub-Saharan Africa. New perspectives.

22.Neaime, S., (2002), October. Liberalization and financial integration of MENA stock markets. In $A$ paper presented at the ERF's 9 th annual conference on Finance and Banking.

23.Nnadozie, E., Munthali, T. C., Nantchouang, R., \& Diawara, B. (2017). Domestic resource mobilization in Africa: Capacity imperatives. In Development Finance (17-49). Palgrave Macmillan, Cham.

24.Nyasha, S., \& Odhiambo, N. M. (2015). Do banks and stock markets spur economic growth? Kenya's experience. International Journal of Sustainable Economy, 7(1), 54-65.

25.Oji, C. K., (2015). Bonds: A Viable Alternative for Financing Africa's Development. The South African Institute of International Affairs (SAIIA).

26.Peria, M. M. S. M., \& Schmukler, M. S. L. (2017). Understanding the Use of Long-term Finance in Developing Economies. International Monetary Fund.

27.Sacerdoti, M. E. (2005). Access to bank credit in sub-Saharan Africa: key issues and reform strategies (No. 5-166). International Monetary Fund.

28.Sassi, S., \& Goaied, M. (2013). Financial development, ICT diffusion and economic growth: Lessons from MENA region. Telecommunications Policy, 37(4-5), 252-261.

29.Taglioni, D., Winkler, D., Athukorala, P. C., Baldwin, R., Lopez-Gonzalez, J., Calì, M., ... \& RojasRomagosa, H. (2016). World Investment Report 2013-Global Value Chains: Investment and Trade for Development. Manila: United Nations Industrial Development Organization.

30.Tyson, J. (2015). Sub-Saharan Africa international sovereign bonds. Overseas Development Institute.

31.UNCTAD. (2013). World Investment Report 2013. Global Value Chains: Investment and Trade for Development. Geneva: United Nations Conference on Trade and Development.

32. World Bank. (2019). World Bank national accounts data, and OECD National Accounts data files,

World Development Indicators Database. Washington, DC: The World Bank.

33.Zhang, T., \& Matthews, K. (2019). Assessing the degree of financial integration in ASEAN-A perspective of banking competitiveness. Research in International Business and Finance, 47, 487-500. 